\title{
Impaired Cellular Immunity in Kwashiorkor with Improvement after Therapy
}

\section{Introduction}

Infection is prevalent in malnourished infants, and both bacterial and viral infections often follow a fulminating course in patients suffering from kwashiorkor (Smythe, 1958; Wittman et al., 1967; Scrimshaw et al., 1968). Published studies of immunoglobulin levels in infants with protein-calorie malnutrition do not suggest a defect in humoral immunity in this disease (Keet and Thom, 1969; Aref, 1970; Watson and Freeseman, 1970; El-Gholny et al., 1970; McFarland et al., 1970). Jackson (1925) and Vint (1936-7) reported that malnourished children show atrophy of the thymus and lymphoid tissue, so we tested cell-mediated immunity in malnutrition in a prospective study in children with kwashiorkor by the cutaneous delayed hypersensitivity reaction to antigens, and by the in-vitro transformation of lymphocytes by phytohaemagglutinin.

\section{Patients}

Eighteen African children aged 6 to 30 months admitted to Baragwanath Hospital, Johannesburg, were investigated. All had kwashiorkor as defined by Jelliffe (1966) and their weight was below the third Boston percentile for age. The severity of kwashiorkor on admission was assessed by the presence or absence of the following criteria (Kahn, 1959; Garrow and Pike, 1967): gross oedema, weeping dermatosis, severe wasting in the presence of oedema and dermatosis, hepatomegaly of $4 \mathrm{~cm}$ or more below the costal margin, jaundice, prothrombin index of $50 \%$ or less, disturbance of consciousness with or without hypoglycaemia, dehydration and/or electrolyte disturbance, the presence of infection, hypothermia to $95^{\circ} \mathrm{F}\left(35^{\circ} \mathrm{C}\right)$ or

Baragwanath Hospital, Johannesburg, South Africa

J. GEEFHUYSEN, D.C.H., M.R.C.P.ED., Paediatrician

E. U. ROSEN, D.C.H., M.MED.PAED., Paediatrician

Haematology Department, School of Pathology, University of the Witwatersrand, and South African Institute for Medical Research, Johannesburg, South Africa

J. KATZ, M.B., B.CH., F.C.P.(s.A.), Haematologist

T. IPP DIP.MED, Pathologist

J. METZ, M.D., M.R.C.PATH., Professor of Pathology (Haematological),

less, and xerophthalmia. When four or more of these features were present the cases were regarded as "severe"; when at least one but fewer than four were present the cases were graded as "moderate," and "mild" cases had none of these poor prognostic criteria. Overt clinical evidence of infection was present in 13 of the 18 patients.

All patients were given a standard diet of $\pm 200 \mathrm{ml} / \mathrm{kg} /$ day of $66.6 \%$ Pelargon with added sucrose. This provided nearly $130 \mathrm{cal} / \mathrm{kg} /$ day and $4.5 \mathrm{~g}$ protein $/ \mathrm{kg} /$ day. Feeding by nasogastric tube was often required initially. Potassium supplements and vitamins $A, D$, and $C$ were given routinely, and intravenous fluids and antibiotics were administered when indicated. The surviving children were retested three weeks later when they showed considerable clinical improvement and weight gain.

Control Subjects.- The control group comprised nine wellnourished African children aged 6 to 18 months at the 50th Boston percentile for weight. All nine children had clinical evidence of infection-namely, gastroenteritis, otitis media, and pneumonia-similar to those diagnosed in the children with kwashiorkor.

\section{Methods}

Cutaneous Delayed Hypersensitivity Reactions.-Skin tests with diphtheria toxoid and candida antigen were carried out on admission to hospital on all patients and controls and, if negative, were repeated after three weeks. Diphtheria toxoid: $0.1 \mathrm{ml}$ of a $1 / 10$ dilution was injected intradermally with a tuberculin syringe into the flexor surface of the forearm. The reaction was read after 48 hours. Candida antigen*: A somatic antigen was provided in a cream base. The material was applied to the flexor surface of the forearm and introduced into the skin with a Heaf gun set at $2 \mathrm{~mm}$. The reactions were read at 48 and 72 hours.

In-vitro Lymphocyte Transformation.-Human peripheral blood leucocytes were cultured as described previously (Liknaitzky et al., 1970). Ten millilitres of blood was collected aseptically in heparin (20 units per $\mathrm{ml}$ of blood), allowed to stand at room temperature for 45 minutes, and the supernatant leucocyte-rich plasma aspirated. The leucocyte suspension, which contained $>70 \%$ lymphocytes, was then added to $\mathrm{M} 150$ medium and $10 \%$ bovine albumin to give a concentration of $1 \times 10^{6}$ lymphocytes per $\mathrm{ml}$. The cultures were incubated at $37^{\circ} \mathrm{C}$ for three days after the addition of $0.1 \mathrm{ml}$ of phytohaemagglutinin. After three days the cells were harvested and fixed in $75 \%$ alcohol and $25 \%$ glacial acetic acid. Two slides were prepared from each culture, stained with Wright's stain, and the cells counted. A total of 500-1,000 cells were counted and recorded as "transformed" or "small" lymphocytes. Unstimulated lymphocyte cultures were set up from each patient as controls. The number of transformed (stimulated) lymphocytes was expressed as a percentage of the total number of lymphocytes as follows:

lymphocyte transformation index $=\frac{\text { transformed cells }}{\text { total no. cells counted }} \times 100$

Serum immunoglobulins were estimated in 12 patients by the Hyland monospecific immunoplate method. $\dagger$

*Glaxo Laboratories, London, England. Kindly supplied by Professo * Glaxo Laboratories, London, Engla †Hyland Laboratories, Los Angeles, California. 
TABLE II-Tests of Cellular Immunity and Immunoglobulin Levels in 18 Children with Kwashiorkor on Admission to Hospital, and after 3 Weeks' Treatment

\begin{tabular}{|c|c|c|c|c|c|c|c|c|c|c|c|c|c|}
\hline \multirow{3}{*}{\multicolumn{2}{|c|}{$\begin{array}{l}\text { Case } \\
\text { No. }\end{array}$}} & \multirow{3}{*}{$\begin{array}{l}\text { Age in } \\
\text { Months }\end{array}$} & \multirow{3}{*}{$\begin{array}{l}\text { Clinical } \\
\text { Severity }\end{array}$} & \multirow{3}{*}{$\underset{\text { Infections* }}{\text { Clinical }}$} & \multicolumn{4}{|c|}{ Skin Reactions } & \multirow{2}{*}{\multicolumn{2}{|c|}{$\begin{array}{c}\text { Lymphocyte Trans- } \\
\text { formation Index } \\
(\%)\end{array}$}} & \multirow{2}{*}{\multicolumn{3}{|c|}{$\begin{array}{l}\text { Immunoglobulin Levels } \\
(\mathrm{mg} / 100 \mathrm{ml})\end{array}$}} \\
\hline & & & & & \multicolumn{2}{|c|}{ Candida } & \multicolumn{2}{|c|}{ Diphtheria } & & & & & \\
\hline & & & & & Initial & Repeat & Initial & Repeat & Initial & Repeat & IgG & IgA & IgM \\
\hline $\begin{array}{r}1 \\
2 \\
3 \\
4 \\
5 \\
6 \\
7 \\
8 \\
9 \\
10 \\
11 \\
12 \\
13 \\
14 \\
15 \\
16 \\
17 \\
18\end{array}$ & $\begin{array}{l}. . \\
\ldots \\
\ldots \\
\ldots \\
\ldots \\
\ldots \\
\ldots \\
\ldots \\
\ldots \\
\ldots \\
\ldots \\
\ldots\end{array}$ & $\begin{array}{r}22 \\
12 \\
15 \\
12 \\
6 \\
12 \\
17 \\
19 \\
12 \\
30 \\
15 \\
12 \\
14 \\
15 \\
18 \\
12 \\
12 \\
7\end{array}$ & $\begin{array}{l}\text { Mild } \\
\text { Mild } \\
\text { Moderate } \\
\text { Moderate } \\
\text { Moderate } \\
\text { Moderate } \\
\text { Moderate } \\
\text { Moderate } \\
\text { Severe } \\
\text { Severe } \\
\text { Severe } \\
\text { Severe } \\
\text { Severe } \\
\text { Severe } \\
\text { Severe } \\
\text { Severe } \\
\text { Severe } \\
\text { Severe }\end{array}$ & $\begin{array}{l}\text { No } \\
\text { No } \\
\text { Yes } \\
\text { Yes } \\
\text { Yes } \\
\text { No } \\
\text { No } \\
\text { Yes } \\
\text { No } \\
\text { Yes } \\
\text { Yes } \\
\text { Yes } \\
\text { Yes } \\
\text { Yes } \\
\text { Yes } \\
\text { Yes } \\
\text { Yes } \\
\text { Yes }\end{array}$ & $\begin{array}{l}- \\
\pm \\
+ \\
\pm \\
= \\
= \\
= \\
= \\
= \\
= \\
= \\
= \\
= \\
= \\
-\end{array}$ & $\begin{array}{l}+ \\
\text { N.T. } \\
\text { N.T. } \\
\text { N.T. } \\
+ \\
+ \\
+ \\
+ \\
+ \\
\text { Died } \\
\text { Died } \\
\text { N.T. } \\
+ \\
+ \\
+ \\
+ \\
+ \\
\text { Died } \\
\text { Died }\end{array}$ & $\begin{array}{l}- \\
\overline{-} \\
\pm \\
\pm \\
= \\
= \\
= \\
\pm \\
\pm \\
\pm \\
\pm \\
\pm \\
= \\
= \\
-\end{array}$ & $\begin{array}{c}+ \\
+ \\
+ \\
+ \\
+ \\
- \\
+ \\
+ \\
+ \\
\text { Died } \\
\text { Died } \\
\text { N.T. } \\
\text { N.T. } \\
+ \\
+ \\
+ \\
\text { Died } \\
\text { Died }\end{array}$ & $\begin{array}{c}30 \\
64 \\
60 \\
78 \\
68 \\
45 \\
7 \\
\text { N.T. } \\
52 \\
33 \\
51 \\
45 \\
40 \\
33 \\
14 \\
5 \\
52 \\
\text { N.T. }\end{array}$ & $\begin{array}{l}\bar{z} \\
= \\
= \\
= \\
30 \\
= \\
= \\
= \\
= \\
\overline{3} \\
\text { N.T. } \\
= \\
=\end{array}$ & $\begin{array}{r}1,200 \\
750 \\
- \\
1,350 \\
1,250 \\
1,600 \\
800 \\
750 \\
820 \\
100 \\
940 \\
- \\
820 \\
940 \\
= \\
= \\
-\end{array}$ & $\begin{array}{l}350 \\
190 \\
- \\
240 \\
145 \\
- \\
130 \\
110 \\
97 \\
180 \\
260 \\
270 \\
= \\
230 \\
370 \\
= \\
= \\
-\end{array}$ & $\begin{array}{r}36 \\
58 \\
- \\
74 \\
68 \\
\overline{135} \\
80 \\
86 \\
90 \\
100 \\
90 \\
\overline{62} \\
48 \\
= \\
-\end{array}$ \\
\hline
\end{tabular}

*Overt clinical infections include otitis media, gastroenteritis, herpes simplex, pneumonia, and skin sepsis. N.T. = Not tested.

\section{Results}

Positive candida and diphtheria toxoid skin tests were significantly less frequent in children with kwashiorkor than in control children $\left(\chi^{2}=10.14 ; \mathrm{P}<0.005\right.$ for candida, and $\chi^{2}=8.70 ; \mathrm{P}<0.005$ for diphtheria toxoid) (see Tables I and II). After three weeks of hospital treatment the skin reaction to candida became positive in all 10 patients with kwashiorkor retested (Table II), a statistically significant increase $\left(\chi^{2}=\right.$ 14.75; $\mathrm{P}<0.005)$, and positive diphtheria skin tests were obtained in 10 of the 12 patients retested $\left(\chi^{2}=15.56 ; \mathrm{P}<0.005\right)$.

TABLE I-Tests of Cellular Immunity in 9 Well-nourished Control Infants with Intercurrent Infections

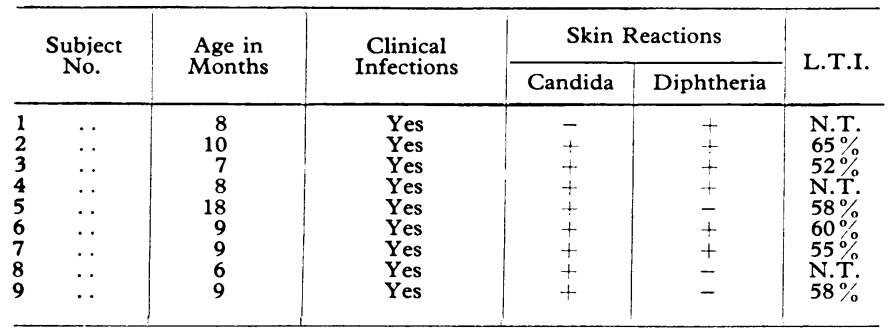

L.T.I.-Lymphocyte transformation index. N.T. = Not tested.

The lymphocyte transformation index was determined in six of the nine control children and in 16 children suffering from kwashiorkor, and the results are shown in the Chart. The mean lymphocyte transformation index was $58.0 \pm 1.63 \%$ in the control children and $42.5 \pm 5.33 \%$ in the kwashiorkor patients. The difference between the two means is statistically significant $(t=3.33 ; \mathrm{P}<0.005)$. Two patients with low initial values were retested after three weeks, when their nutritional state had improved, and in both of them the index had risen to $30 \%$.

The four patients with lymphocyte transformation index values greater than $60 \%$ showed the least disturbance of the candida skin test reaction; three of these had a positive candida response initially. In the six children with an index of $40-59 \%$ the skin test responses were variable, and the six patients with an index of less than $40 \%$ showed the maximum suppression of cutaneous delayed hypersensitivity.

It was possible to correlate the clinical severity of kwashiorkor with the results of the tests of cellular immunity. The three children with positive candida reactions and lymphocyte transformation index of $60 \%$ or greater showed mild or moderate kwashiorkor. In all children with severe disease the candida reaction was negative and the lymphocyte transformation index less than $55 \%$. Two infants (Cases 1 and 7, Table II), however, showed poor correlation between the clinical findings and both the skin tests and the lymphocyte transformation index.The skin tests initially were negative and the lymphocyte transformation index was $<40 \%$, yet clinical criteria suggested only mild or moderate clinical kwashiorkor. Of the 12 patients who showed definite diminished cutaneous delayed hypersensitivity initially, four died.

The serum immunoglobulin levels in the 12 patients tested are shown in Table II. IgG levels ranged from 100 to 1,600

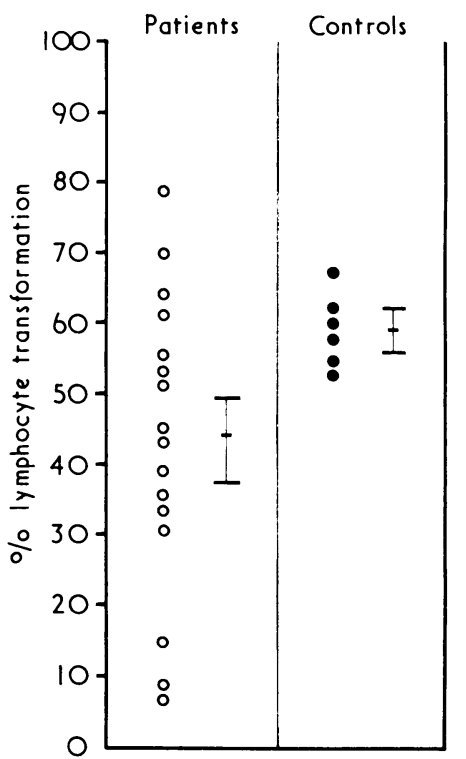

Lymphocyte transformation index after PHA stimulation in 16 patients with kwashiorker and six well-nourished control infants of comparable age, with intercurrent infection.

$\mathrm{mg} / 100 \mathrm{ml}$, IgA from 97 to $370 \mathrm{mg} / 100 \mathrm{ml}$, and IgM from 36 to $135 \mathrm{mg} / 100 \mathrm{ml}$. There was no correlation with clinical infection or the degree of severity of the kwashiorkor. Of the two patients who died, one had a low IgG, with raised IgA and a normal IgM, whereas the second had normal immunoglobulin levels for his age.

\section{Discussion}

Harland (1965), Lloyd (1968), and Hutt (1969) showed that the delayed response to the tuberculin skin test is diminished in malnourished children. We have obtained similar results using diphtheria toxoid and candida. These antigens are appropriate because of the high probability of previous contact by immunization and candida infections (Fireman et al., 1969). 
This choice was validated by the finding that the candida skin tests were positive in eight of the nine controls and converted to positive in most of the surviving children with kwashiorkor after refeeding. This recovery of function with feeding suggests that the defect is directly related to the nutritional status. Our finding of impaired lymphocyte transformation to phytohaemagglutinin, not to our knowledge previously reported in malnutrition, is consistent with these findings.

The correlation between lymphocyte transformation, delayed cutaneous hypersensitivity, and clinical grading of severity of kwashiorkor, and the improvement after refeeding, support the premise that lymphoid cell function is partly dependent on protein availability.

This defect of delayed hypersensitivity in infants with kwashiorkor may contribute to their high incidence and great severity of infection, though other factors such as non-specific immunity, exposure to infections, and socioeconomic conditions may be important. The finding of a normal lymphocyte transformation index and positive reactions to the skin antigens in a group of well-nourished but infected children indicates that in kwashiorkor the impaired lymphocyte function is related to protein deprivation rather than to the presence of infection.

We thank the Superintendent, Dr. C. Kniep, and the acting head of the department of paediatrics, Professor S. Wayburne, for permission to publish, and the Director, South African Institute for Medical Research, for facilities to carry out this study, which was supported by a research grant from the S.A. Medical Research Council.

Requests for reprints should be sent to Dr. J. Katz, South African Institute for Medical Research, P.O. Box 1038, Johannesburg, South Africa.

\section{References}

Aref, G. H. (1970). Fournal of Tropical Medicine and Hygiene, 73, 186. El-Gholny, A., Helmy, O., Hashish, S., Aly, R. H., and El-Gamal, Y. (1970). Fournal of Tropical Medicine and Hygiene, 73, 192

Fireman, P., Friday, G., and Kumate, J. (1969). Pediatrics, 43, 264.

Garrow, J. S., and Pike, M. C. (1967). British Fournal of Nutrition, 21, 155.

Harland, P. S. E. G. (1965). Lancet, 2, 719.

Hutt, M. S. R. (1969). Fournal of Tropical Paediatrics, 15, 153.

Jackson, G. M. (1925). The Effects of Inanition and Malnutrition upon Growth and Structure. Philadelphia, Blakiston.

Jelliffe, D. B. (1966). World Health Organization. Monograph Series, No. 53, p. 179.

Kahn, E. (1959). American fournal of Clinical Nutrition, 7, 161.

Keet, M. B., and Thom, H. (1969). Archives of Disease in Childhood, 44, 600

Liknaitzky, D., Katz, J., and Metz, J. (1970). South African Medical fournal, 44, 756 .

Lloyd, A. V. C. (1968). British Medical fournal, 3, 529

McFarlane, H., Reddy, S., Cooke, A., Onabamiro, M. O., and Houba, J. E. (1970). Tropical and Geographic Medicine, 22, 61.

Scrimshaw, N. S., Taylor, C. E., and Gordon, J. E. (1968). World Health Organization. Monograph Series, No. 57.

Smythe, P. M. (1958). Lancet, 2, 724

Vint, F. W. (1936-7). East African Medical fournal, 13, 332.

Watson, G. E., and Freeseman, G. (1970). Archives of Disease in Childhood, $45,282$.

Wittman, W., Moodie, A. D., Fellingham, S. A., and Hansen, J. D. L. (1967). South African Medical fournal, 41, 664.

\section{PRELIMINARY COMMUNICATIONS}

\section{Lymphocyte Response Depressive Factor in Multiple Sclerosis}

\author{
E. J. FIELD, E. A. CASPARY
}

British Medical fournal, 1971, 4, 529-532

\section{Summary}

Normal serum contains a lymphocyte response depressive factor and this is more active against the lymphocytes of the blood from which the serum was obtained than against lymphocytes from a different normal blood. The suppressive factor is thus "tailor-made" to its own lymphocytes though cross-reactivity with other lymphocytes does occur. The significance of this is discussed. The suppressive factor has a higher titre in serum from patients with multiple sclerosis or other destructive neurological disease than in normal serum. This may be an instance of a general phenomenon in which lymphocyte sensitization is ordinarily accompanied by production of a suppressor factor able to damp down response so that this is controlled by an "acceleratorbrake" mechanism. The possibilities of imbalance in the pathogenesis of disease and therapeutic manipulation of the level of suppressor substance are briefly discussed.

Medical Research Council Demyelinating Diseases Unit, Newcastle General Hospital, Newcastle upon Tyne, NE4 6BE

E. J. FIELD, M.D., F.R.C.P., Professor of Experimental Neuropathology E. A. CASPARY, M.SC., Member of Scientific Staff

\section{Introduction}

Whatever the aetiology of multiple sclerosis (M.S.) may ultimately turn out to be-infective or autoimmune-it is difficult to escape the conclusion that immunological processes (and delayed hypersensitivity in particular) play a part in the genesis of recurrent episodes of the disease. Since delayed hypersensitivity depends on lymphocyte sensitization and the autoaggression of these cells is believed to produce the disease, any means of damping-down the reactivity of such lymphocytes is of potential therapeutic importance. In the case of M.S. the putative antigen is a basic protein extractable from human brain (Caspary and Field, 1965, 1971a) and capable of producing experimental allergic encephalomyelitis in animals.

In multiple sclerosis (Hughes, Caspary, and Field, 1968; Knowles, Hughes, Caspary, and Field, 1968; van den Noort and Stjernholm, 1971) as well as in a whole variety of other conditions such as tuberculosis (Heilman and McFarland, 1966), hepatitis (Paronetto and Popper, 1970), secondary syphilis (Levene, Turk, Wright, and Grimble, 1969), ataxia telangiectasia (McFarlin and Oppenheim, 1969), and chronic candidiasis (Canales, Middlemas, Louro, and South, 1969) among others, serum has been shown to contain a factor which is able to damp down lymphocytic response to antigen. The present work studies the titre of this lymphocyte depressive factor in normal serum and in serum from patients with M.S. and other (destructive) neurological diseases. The isolation and characterization of the lymphocyte depressive factor might be of considerable therapeutic importance in the treatment of diseases due to "autoaggression" by these cells.

Research in human lymphocyte sensitization has hitherto been much hampered by the absence of a sensitive, reproducible, and quantitative method of estimation (Bloom, 1971), but recently we have described one such which we believe has these attributes-the macrophage electrophoretic slowing test (Field and Caspary, 1971b; Caspary and Field, 1971b) -and this has been used in the present work. Its principle is described below. 